\title{
Aluminium Manufacture in Great Britain
}

W ITH the exception of silicon, aluminium is probably the most abundant metal in the world, forming nearly one eighth of the earth's crust. Owing to the ready manner with which it combines with oxygen, it is never found, as most other metals are, in the metallic state. In a paper in the 'Aluminium Section' of the March issue of the "Trade and Engineering Supplement" of The Times, Mr. W. Murray Morrison gives an outline of the position which the aluminium industry now occupies in the British Isles.

In 1921, the Lochaber Power Co. was formed and developed a large water-power station. When completed, this scheme will be capable of developing 100,000 h.p. continuously, and will be by far the largest hydro-electric development in Great Britain. The British Aluminium Co. operates three reduction works, at Foyers, Kinlochleven and Lochaber. These are supplied with pure aluminium oxide from their works at Lame in Ireland and Burntisland in Scotland. These works in turn are supplied with crude ore, bauxite, from the Company's own mines, vast deposits being owned by it in the south of France and in some British colonies. There is one other producer of the crude metal in Great Britain, namely, the Aluminium Corporation, the supplies of alumina for which are produced at Hebburn-on-Tyne and reduced to the metal at Dolgarrog, North Wales.

The final forms in which aluminium reaches the public cover a very wide field. The two forms in which it is best known are for cooking utensils and foil. The advantages of aluminium vessels for cooking are their lightness, cleanliness, hygienic qualities and heat conductivity, together with their immunity from chipping, rusting and burning; these properties have made them very popular. Aluminium foil has almost entirely replaced other kinds of metal foil and is adopted for the wrapping of cigarettes and chocolates, the capping of milk bottles and tea-chest linings.

In connexion with motor-cars, aluminium pistons are now very commonly employed. Aluminium, which is only one third the weight of iron or copper, made possible the remarkable increase in the speed of transport which has taken place during the last fifty years. Motor-vehicle owners are keenly alive to the fact that it costs a given sum to convey a given weight a given distance in a given time. There is an additional advantage of using aluminium in road vehicles, as the increased lightness sometimes saves an appreciable part of the motor tax in Great Britain and allows the vehicle to run at a higher speed.

In air transport, where lightness is a paramount consideration, aluminium and its alloys play a very important part. Only one metal lighter than aluminium, namely, magnesium, is used as the major constituent in the manufacture of light alloys. The production of magnesium is closely allied to the aluminium industry. For these two metals and their alloys the aircraft industry depends for many of its components.

In electrical transmission, aluminium has been most useful. In Great Britain, the transmission lines of the National Grid alone employ more than 20,000 miles of steel-cored aluminium cable.

\section{Association for the Study of Systematics in Relation to General Biology}

A $N$ opening meeting of the "Association for the $A$ Study of Systematics in Relation to General Biology" was held in the rooms of the Linnean Society (by kind permission of the president and council) on Friday, June 25. The chairman of the Association, Dr. Julian Huxley, presided over a gathering of seventy-four biologists.

In his introductory remarks, Dr. Huxley outlined the history of the Association. He said that the movement commenced with informal meetings in the autumn of 1936 between certain members of the staff of the Royal Botanic Gardens, Kew, and the John Innes Horticultural Institution at Merton. These led to the formation, on May 3, 1937, of a joint zoological and botanical "Committee on Systematics in Relation to General Biology". This committee eventually changed its title to the present form, and a council and seven committees were elected. The council at present consists of the following biologists : J. S. Huxley (chairman of the Association), H. W. Parker (zoological secretary), J. S. L. Gilmour (botanical secretary), W. T. Calman, G. S. Carter, M. B. Crane, C.D. Darlington, C. Diver, E. B. Ford, R. Ruggles Gates,
H. Godwin, J. W. Gregor, M. A. C. Hinton, J. R. Norman, J. Ramsbottom, O. W. Richards, N. D. Riley, E. J. Salisbury, Miss B. Schafer, T. A. Sprague, W. B. Turrill, B. P. Uvarov, E. B. Worthington, Sir W. Wright-Smith.

Dr. Huxley then explained the aims of the Association, which may be summarized under the following heads :

(I) To examine the theoretical and historical bases and the practical aims of taxonomy, and especially the relation of phylogeny to cytogenetic and taxonomic data.

(2) To examine the criteria employed in defining species and other systematic categories in different groups and the possibility of obtaining greater uniformity in their usage.

(3) To consider how far in the light of cytogenetic, ecological, physiological, embryological, and palæontological data, existing classification might require to be modified and new subsidiary terminology to be introduced. Further, to investigate the relation of any such subsidiary terminology to the International Rules of Nomenclature. 
(4) To investigate the data and material already available, either taxonomic or bearing on taxonomy, with the view of correlating them with general biological principles and of establishing generalizations in comparative systematics.

(5) To press for the appointment of additional taxonomists and other biologists to the staffs of museums and other appropriate institutions.

(6) To arrange for research into the relative importance of the various factors, internal and external, operative in different groups in producing speciation and other evolutionary processes.

(7) To co-operate in the production or improvement of handbooks on British animals and plants and in the eventual publication of a British Fauna and Flora on uniform biological lines.

(8) To suggest useful lines of biological work to natural history societies and to amateurs and to assist in its co-ordination.

(9) To investigate the best methods of teaching systematics and field work in universities and schools.

(10) To stimulate discussion and to promote co-operation between workers in different branches of biology on problems of taxonomic interest.

The committees so far formed, together with the particular items of the aims of the Association with which they are concerned, are as follows:
(1) Taxonomic principles (items 1-3). Convener : Mr. J. S. L. Gilmour, Royal Botanic Gardens, Kew.

(2) Comparative systematics (item 4). Convener : Mr. J. R. Norman, British Museum (Natural History), Cromwell Road, S.W.7.

(3) Research (item 6). Convener : Dr. W. B. Turrill, Royal Botanic Gardens, Kew.

(4) Handbooks (item 7). Conveners : Captain C. Diver, 40 Pembroke Square, W.8; Mr. M. B. Crane, John Innes Horticultural Institution, Merton, S.W.19.

(5) Natural History Societies (item 8). Convener : Mr. H. W. Parker, British Museum (Natural History), Cromwell Road, S.W.7.

(6) Education (item 9). Convener : Miss B. Schafer, John Innes Horticultural Institution, Merton, S.W.19.

(7) Publications (other than handbooks). Convener: Dr. C. D. Darlington, John Innes Horticultural Institution, Merton, S.W.19.

At the close of the meeting, fifty-three biologists, in addition to the existing council and committees, gave in their names as members. Any other biologists wishing to join the Association should send their names and addresses to one of the secretaries, stating in which particular committee they are interested. For the present there is no subscription or formal method of election.

\section{Annual Conference of the Museums Association}

$\mathrm{T}$ HE forty-eighth annual conference of the Museums Association was held in Newcastleupon-Tyne in the week commencing July 5. The chief impression which one gained from the Conference was that museum officials are considering their problems in a new and more critical manner.

The keynote was set by Alderman Charles Squire in his presidential address. As chairman of the Leicester Museums Committee for the past twenty. seven years, he could speak with authority, and did not hesitate to criticize the general failure of municipal councils to make adequate provision for their museums. Museums and art galleries have a high place in the educational and social scheme, and are not yet getting the support which they deserve. Alderman Squire also referred to the valuable work that could be done by museums in assisting to preserve local records and the amenities of the countryside.

Another critical paper was one by Dr. W. E. Swinton (British Museum, Natural History), on "Natural History Museums and the Community". Too many small natural history museums might have as their motto "How best to kill a love of Nature", and Dr. Swinton strongly advocated the elimination of useless material and better display of the collections, so that these might inspire the visitor with a greater interest in plants, animals and rocks in their natural settings. The paper dealt with many other points of practical importance, especially the need for having as curator one who was not only a scientific worker, but also a man of action.

In the same general field there was also a valuable discussion on "Simplifying Habitat Groups", to which Mr. R. K. Perry (Liverpool), Mr. T. Russell Goddard (Newcastle), Mr. W. E. Mayes
(Leicester), and Mr. R. Wagstaffe (Stockport) contributed. It was pointed out that in a zoological exhibit it is most valuable to have an indication of the natural habitat of the birds or animals displayed, but that the elaborate group, to be found in the larger American museums, is far too expensive for the smaller English institutions. The proposals made were in the direction of suggesting habitat by branches of trees, by plants, or by other background material, and by the careful arrangement of the specimens in natural attitudes.

On the archæological side, current museum methods were again criticized, the speaker being $\mathrm{Mr}$. Ian Richmond, of Armstrong College. Mr. Richmond answered the question: "What does an archæologist expect of a museum ?" He suggested that the museum should contain a full series of local maps, especially those showing human distribution at different epochs; that one exhibit at least should display all the objects and clues that had been obtained from a single excavation; and that, wherever possible, comparative series of exhibits should be set up. He also appealed for a simple classified system of storage of all material not on exhibition.

Within the scientific field there were some important papers of a descriptive nature. Thus, Col. E. E. B. Mackintosh, director of the Science Museum, described the special exhibitions which have been developed at that Museum since 1911. It is interesting to learn that these very successful displays, which in recent years have covered such subjects as refrigeration, rubber, electro-deposition, noise and smoke abatement, electric illumination and television, take from six to twelve months to prepare, and that 